\title{
Cytotoxic activity evaluation of chalcones on human and mouse cell lines
}

\author{
Luis Felipe Buso Bortolotto*, Bruna Cestari Azevedo, Gabriel Silva, Mozart Marins, Ana Lucia Fachin \\ From 5th Congress of the Brazilian Biotechnology Society (SBBIOTEC) \\ Florianópolis, Brazil. 10-14 November 2013
}

\section{Background}

The Brazilian National Cancer Institute (INCA) estimated last year almost forty thousand new cancer cases of laryngeal carcinoma, melanoma, tracheal, bronchial and lung cancer. It is known that multidrug resistance and unspecific toxicity are the major challenges for commercial anticancer drugs [1]. In this regard, natural compounds and derivatives are considered as a source of novel antitumor drugs. Among these molecules, chalcones have gained pharmacological importance due its mechanisms of action related to apoptosis induction [2]. Here we characterized the cytotoxicity of four chalcones toward three tumor cell lines: Hep-2 (human laryngeal squamous carcinoma cells), B-16 (mouse melanoma), A549 (human lung adenocarcinoma epithelial cells) and one normal cell line: 3T3 (mouse fibroblasts).

\section{Methods}

The cytotoxicity of chalcones was evaluated by the colorimetric MTT assay, which determines the reduction of tetrazolium into insoluble formazan by mitochondria of viable cells [3]. For this purpose, four chalcones: trans-chalcone; Licochalcone A; 4-Methoxychalcone and 3'-(trifluoromethyl)chalcone were tested against four different cell lines: Hep-2, B-16, A549 and 3T3. The cell culture was carried out by using Dulbecco's Modified Eagle Medium for A549 and 3T3, RPMI 1640 for Hep-2, and F-10 for B-16. All medium were supplemented with fetal calf serum. Each cell line was plated in a 96-well plate $\left(3 \times 10^{4}\right.$ per well) for 24 hours before adding the medium with chalcones in a 5 different concentration treatment $(25,20,15,10$ and $5 \mu \mathrm{g} / \mathrm{mL})$. After 48 hours, compounds were withdrawn and a solution of fresh medium containing 3-(4,5-dimethylthiazol-2-yl)-2,5-diphenyltetrazolium bromide (MTT) was added. After 4 hours of incubation,

Universidade de Ribeirão Preto, Brazil

(c) 2014 Buso Bortolotto et al : licensee BioMed Central Ltd. This is an Open Access article distributed under the terms of the Creative Commons Attribution License (http://creativecommons.org/licenses/by/4.0), which permits unrestricted use, distribution, and reproduction in any medium, provided the original work is properly cited. The Creative Commons Public Domain Dedication waiver (http://creativecommons.org/publicdomain/zero/1.0/) applies to the data made available in this article, unless otherwise stated. the product (formazan) was solved by DMSO. Hereafter, the plates were measured through $550 \mathrm{~nm}$ wavelength analysis, using an ELISA reader. Treatments were compared to negative control (medium with $0.25 \%$ DMSO) and positive control $(2.5 \mu \mathrm{g} / \mathrm{mL}$ doxorubicin). Cytotoxicity was calculated by the formula: percent cytotoxicity $=$ (1-[absorbance of experimental wells/absorbance of control wells] $) \times 100 \%$ [4]. IC $_{50}$ values were also determined. Data were analyzed by the software Sisvar.

\section{Results and conclusions}

The $\mathrm{IC}_{50}$ values for $\mathrm{A} 549$ were $81.29 \mu \mathrm{M}, 81.34 \mu \mathrm{M}, 85.40$ $\mu \mathrm{M}$ and $46.13 \mu \mathrm{M}$ for trans-chalcone, 3'-(trifluoromethyl) chalcone, 4-Methoxychalcone and Licochalcone A, respectively. Hep-2 showed up the most susceptible cell line with $\mathrm{IC}_{50}$ values below $10 \mu \mathrm{g} / \mathrm{mL}$ for trans-chalcone, Licochalcone $\mathrm{A}$ and 3'-(trifluoromethyl)chalcone. $\mathrm{IC}_{50}$ values for Licochalcone A, trans-chalcone, 4-Methoxychalcone and 3'-(trifluoromethyl)chalcone for tumor mouse cell line B-16 were, respectively, $25.89 \mu \mathrm{M}, 45.42 \mu \mathrm{M}, 50.15 \mu \mathrm{M}$ and $61.54 \mu \mathrm{M}$; for non-tumor mouse cell line $3 \mathrm{~T} 3$ were $33.42 \mu \mathrm{M}, 48.40 \mu \mathrm{M}, 64.34 \mu \mathrm{M}$ and $43.44 \mu \mathrm{M}$. All $\mathrm{IC}_{50}$ values for 4-Methoxychalcone were higher than $50 \mu \mathrm{M}$. Thus, among the chalcones tested 4-Methoxychalcone was the least cytotoxic and Licochalcone A the most effective for all cell lines, followed by trans-chalcone and 3'-(trifluoromethyl)chalcone.

\section{Acknowledgements}

This project is financially supported by "Fundação de Amparo à Pesquisa do Estado de São Paulo" (FAPESP), process number 2012/15862-5.

\section{Published: 1 October 2014}

\section{References}

1. Lee C, Raffaghello L, Longo VD: Starvation, detoxification, and multidrug resistance in cancer therapy. Drug resistance updates: reviews and commentaries in antimicrobial and anticancer chemotherapy 2012, 15:114-122.
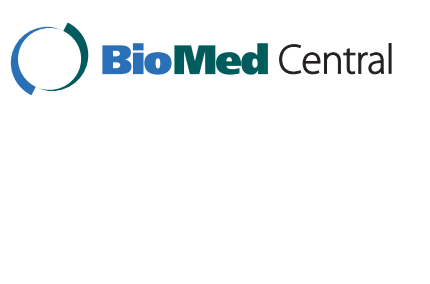
2. Sahu NK, Balbhadra SS, Choudhary J, Kohli DV: Exploring pharmacological significance of chalcone scaffold: a review. Current medicinal chemistry 2012, 19:209-225.

3. Meerloo JV, Kaspers GL, Cloos J: Cell Sensitivity Assays: The MTT Assay. In Cancer Cell Culture. Volume 731. Humana Press;Cree IA 2011:237-245.

4. Szliszka E, Czuba ZP, Mazur B, Paradysz A, Krol W: Chalcones and Dihydrochalcones Augment TRAIL-Mediated Apoptosis in Prostate Cancer Cells. Molecules 2010, 15:5336-5353.

doi:10.1186/1753-6561-8-S4-P52

Cite this article as: Buso Bortolotto et al.: Cytotoxic activity evaluation of chalcones on human and mouse cell lines. BMC Proceedings 2014

8(Suppl 4):P52.

Submit your next manuscript to BioMed Central and take full advantage of:

- Convenient online submission

- Thorough peer review

- No space constraints or color figure charges

- Immediate publication on acceptance

- Inclusion in PubMed, CAS, Scopus and Google Scholar

- Research which is freely available for redistribution

Submit your manuscript at www.biomedcentral.com/submit 